\title{
Situation of Sports in Ilam
}

Ashish Acharya, Lecturer

Kathmandu Shiksha Campus

\begin{abstract}
"Sports is an institutionalized comparative activity that involves various physical extensions or the use of relatively complex physical skills by individuals whose participation is motivated by combination of intrinsic and extrinsic factors. "present situation of sports in illam district entitled research was conducted in illam, where fourty-seven (47) sports related persons were selected as respondents for the study. The main objectives of the study were to find out the developmental trend, present status and prospect of sports in illam district. For this study convenient cum purposive sampling method was used. Different sets of interview schedule was developed including overall issues of the developmental trend present status of sports in Ilam district.
\end{abstract}

Keywords: Situation, participation, techniques, performance, etc

\section{Introduction}

Games and sports are very essential subjects which are the basis of physical, mental, social \& emotional development of an individual. Physical education and sports is those programs which is given learning by doing. Games and sports activities are practical, scientific \& behavioral subjects which are used and apply in daily life of an all individuals. Games and sports are the one of the most applicable procedure of human socialization and adjustment in society. The level of sports and games are depending upon the culture of country. The status of sports can easily determine any country culture and development. Games and sports can be taken as means of social and cultural transmission or hand over process through one generation to another one.

Sports and physical education was the main study subjects for ancient study system. Nowadays sports and physical education is most popular subject in the world. Some countries are more popular in the world by sports. Sports and physical education are the two side of a single coin. In another words, two wheel of one motorcycle. Sports are a one of the importance part of human life.

It has very close relation with our life. Sports are not only the means of maintaining the leisure period, entertainment. But it can play vital role to keep physically, mentally, socially \& emotionally fit of an all individuals. It helps to keep the good relation in the society and also be co-operated to each other's. In hider sense, games and sports refers to be world popular, happiness and joyfulness in life. 
According to Oakley, "Sports are an institutionalized comparative activity that involves various physical extensions or the use of relatively complex physical skills by individuals whose participation is motivated by combination of intrinsic and extrinsic factors."

On that period youth through the stone and get entertainment and show thie power. Throwing stone activities became a shot put games and in the mean time people went to feed the animals on jungle, River bank ...etc. They played the game (Kudimari) that is known as long jump in universal language. Sometimes people played Dandi-bio, Panja ladai, (Kusti) known and Mukaabajee. At that time people study on the basis of mud (Dhulopati) \& they become educated. Slowly the time was passed in 1939 B.S. construct the Ilam Tundikhel (Ilam Estudiam) leadership of Gajrat Singh Thapa.. In that play ground (Tundikhel) shoulders used to do their physical exercise \& others activities. In 1980 B.S football was formally played in team.

In 2008 B.S. Eastern Regional Sports Association (ERSA) was established. In This period their was no achievement. After the Panchayat period in 2018 B.S. Mechi Zone Sports Association (MZSA) was established. only in 2026 B.S District Sports Development Committee Ilam Established. In the history of Ilam in 2010-11 B.S Gajraj Cup football tournament was organized by the name of Gajraj Buddhathoki. In 2015-16 B.S. "Purna Memorial Shield" football tournament organized by the name of Purna Prashai. In 2020 B.S. "Ranbir Shield" tournament was organized by the name of Ranbir Gurung local level wood \& silver are used to construct the Ranbir Shild. All those games were conducted by District Sports Development Committee (DSDC) Ilam. In 2042 B.S. "National women football competition" was conducted in Ilam.

After the earthquake in 2045 B.S. Maivalley Sporting Club organized \& conducted the football tournament to help \& remember those who are facing the problem of earthquake. This tournament was continually organized \& conducted on three years. At that time Mahesh Basnet was the chairmanship of Maivalley Sporting Clubs. Now Many National games is being conducted by districts sports development committee Ilam. In 2070 B.S. National Women Football Competition was conducted by DSDC.

Each administrative district have their own District Sports Development Committee (DSDC) for improving games and sports. There was also a district sports development committee in Ilam district and has been functioning since long. The study is done to find out the contribution of the DSDC Ilam for the development of sports in the local level such as-village, district, region and also it contribution in national level. The study makes us of the data collected through interview schedules and secondary data by the Districts Sports Development Committee (DSDC) Ilam, Nepal. 


\section{Results and discussion}

\section{Players participation}

Various games were played in the president cup tournament 2071/2072. The table mentioned below shows the recored of participation in the tournament. The table shows $56.76 \%$ boys participated in tournament. Where has $43.24 \%$ girls participated in the tournament. Participation of boys and girls was satisfaction which will give better outcome in the future. Systematic training and minimum facilities would raise the participant percentage in upcoming days.

Table 1: Records of players participated in president cup tournament 2071/072

\begin{tabular}{llcccccc}
\hline Sn & \multicolumn{1}{c}{ Games } & No. of & $\mathbf{( \% )}$ & No. of & $\mathbf{( \% )}$ & Total & $\mathbf{( \% )}$ \\
& & boys & & girls & & & \\
1. & Athletics and Volleyball & 295 & 54.62 & 245 & 45.38 & 540 & 100 \\
2. & Taekwondo & 32 & 78.05 & 9 & 21.95 & 41 & 100 \\
3. & Karate & 37 & 52.12 & 34 & 47.88 & 71 & 100 \\
4. & Ushu & 22 & 78.57 & 6 & 21.43 & 28 & 100 \\
& Grand total & 386 & - & 294 & - & 680 & - \\
& Percentage & $56.75 \%$ & - & $43.24 \%$ & - & $100 \%$ & - \\
\hline
\end{tabular}

Source: DSDC, Ilam.

\section{Present Status of the Players}

Players are very important aspects of games and sports. Players are very great person on the fields of games and sports. If players can get enough training, technique, tactic...etc, the players can shows the quality. Similarly if players will be confident then only they perform good. But the players have no any practice, training, coaching activities then they cannot perform in tournaments. In games \& sports, players should be happy, interested, confident \& joyful to participate in tournament, If they don't have interest to participate in tournament it can be there last tournament for him/her. In present context there are less opportunity in sports. Some players are working on school, and some are working on clubs/association. In Ilam districts, there is not proper facilities for players, if the players get facilities they can highly progress in the field of games $\&$ sports. The need of ground, court, field, covered hall...etc is most emerging challenge in illam district. Ilam is that place where players are produced in the eastern region of our country. Karate, Ushu, Takendo, football, volleyball, cricket, athletics are mainly developed games in Ilam districts minimum training are also conducted for 
players, coach \& those person who want to participate in games \& sports. Most of the players are participated on football, volleyball, Karate in Ilam.

Table 2: Academic qualification and training schedule of players

\begin{tabular}{|c|c|c|c|c|c|}
\hline \multirow{2}{*}{ Games } & \multicolumn{3}{|c|}{ Level } & \multirow{2}{*}{ A.C qualification } & \multirow{2}{*}{ Training } \\
\hline & District & Regional & National & & \\
\hline Football & 17 & - & - & S.L.C above & DSDC/NIS/NFA \\
\hline Volleyball & 17 & 2 & - & S.L.C above & DSDC/NVA \\
\hline Athletic & 23 & 4 & 2 & S.L.C + I. ed. & DSDC/NIS/NSC \\
\hline Tekando & 21 & 2 & - & S.L.C above +I.ed. & DSDC Ilam \\
\hline Ushu & 11 & - & - & S.L.C above & DSDC Ilam \\
\hline Karate & 23 & 7 & 4 & S.L.C + I. ed. & DSDC/NIS/NSC \\
\hline Table Tennis & 7 & - & - & S.L.C above & DSDC Ilam \\
\hline Chess & - & - & - & - & - \\
\hline Badminton & - & - & - & - & - \\
\hline \multicolumn{6}{|c|}{ Source: DSDC, Ilam } \\
\hline \multicolumn{6}{|c|}{$\begin{array}{l}\text { Mostly above games are focused on Ilam districts, according to the table no.2. } \\
\text { otball has got district training from DSDC/NIS/NFA, and academic qualification } \\
\text { participator is S.L.C and above. Similarly, volleyball training for players by } \\
\text { SDC/NVA has also determined the academic qualification of S.L.C passed and above } \\
\text { rewise in the field of athletics districts/regional/national level training also conducted } \\
\text { DSDC/NIS for the better performance towards the players it also determine the } \\
\text { ademic qualification of the players has S.L.C passed, I. Ed. passed \& above. Those } \\
\text { ayers who are interested to playing Tekando and Ushu gets district/regional level } \\
\text { ining for the better achievement in local level, these training are conduct and provides } \\
\text { DSD Ilam. Similarly, Karate players gets district/regional/national level training } \\
\text { r achieving best result. These training are specially conducted by DSDC/NIS/NSC } \\
\text { also determines the academic qualification of the players are passed S.L.S and I. } \\
\text { level \& above. Likewise those who are interested to play Table Tennis they also } \\
\text { t special training for local level. This kind training provides or motivates players } \\
\text { wards skills development, technique \& tactics. Especially these training are being } \\
\text { nducted by DSDC Ilam.. }\end{array}$} \\
\hline
\end{tabular}

\section{Conclusion}

In this study, the researcher tried to find out the present situation and prospects for the development of sports. Interview questionnaire schedule were used as the main 
tools of data collection to cover the objectives of this study. The main objectives of this study were found out the developmental trend, present status and prospects of sports in DSDC Ilam. The study has aimed to find out the plan and policy programs, strategies, problems and challenges for the development and improvement of sports in Ilam districts. The major findings of study were the DSDC Ilam was established in 2026 B.S. After establishing the DSDC it organized many sports tournaments. DSDC provides different training, it has sufficient amount for the development of sports and games, and DSDC has playing vital role for conservation and promotion society, education, tourism, environment and cultural aspect. There was good prospects of sports in Ilam district on the basis of above task and present situation of sports in Ilam.

\section{References}

Chhetri, M.B.P. (2015). Role of local organization/clubs for the development of volleyball games in Dadhing district. Unpublished Master's Degree Thesis, department of health and physical education, Tribhuvan University.

Jha A.K. (2066). Test, Measurement and Evaluation in Physical Education. Nepal, Ranu Prakashan.

Khanal. P. (2068). Educational research methodology, Kathmandu: Student Book and Distributor.

Lamsal. T. (2015). Retrospect and prospect of cricket games in Nepal. Unpublished Master Degree Thesis, department of health and physical education, Tribhuvan University.

Maharjan, R.K. (1987). Analytical study of sports facilities and programs of physical education in the school of Nepal. Unpublished, department of health and physical education, Tribhuvan University.

Neure, D.P. (2069). Research methodology, Kathmandu: Quest Publication.

Niroula, I. (2013). A study on historical development of volleyball games in Nepal. Unpublished Master's Degree Thesis Tribhuvan University.

Rana, C.B. (2012). Contribution of sports organization/clubs for the Development of Sports in Parbat District. An unpublished Master Degree Thesis, Tribhuvan University.

Singh, A and et.al. Fourth Edition (2012). Essential of physical education, New Delhi: Kalyni publication.

Singh, H. (1993). Science of sports training. New Delhi: D.V.S. Publication. 